Case Report

\title{
Social Impact Investing for Marginalized Communities in Hong Kong: Cases and Issues
}

\author{
Michael Chak Sham Wong * and Richard Chin Yee Yap \\ College of Business, City University of Hong Kong, Kowloon Tong, Hong Kong, China; \\ richardyap001@gmail.com \\ * Correspondence: efmcw103@cityu.edu.hk
}

Received: 31 March 2019; Accepted: 9 May 2019; Published: 17 May 2019

\begin{abstract}
This paper documents three business cases of social impact investing (SII) for marginalized communities in Hong Kong. Target stakeholders of the cases include displaced old tailors, elderly and wheelchair-bound people, and single-parent families. They are all privately-owned and profit-driven entities with their own social missions. Information on the cases is collected from structured interviews and meetings with their founders and stakeholders. The paper further discusses general issues of SII in Hong Kong and possible mechanisms to support SII development. Tax exemption for investors and donors, related government subsidy schemes, certification on social impacts, and establishment of social impact funds would help SII business thrive in the future.
\end{abstract}

Keywords: social impact investing; social impact fund; revenue generating social organization; social business; Hong Kong

\section{Introduction}

Social impact investing (SII) has gained much attention globally for the last two decades. The notion of "doing well and doing good" is an attractive proposition to endowment funds and charity funds. Impact investing has developed itself to be an asset class for professional institutions such as pension funds, endowments, and banks in the form of investible funds. According to the statistic compiled by the US Forum for Sustainable and Responsible Investment [1], SII grew from USD 500 billion in 1995 to USD 3.6 trillion in 2012, of which USD 1.5 trillion as allocated to investing in social businesses. Global Impact Investing Network (GIIN) estimates in 2018 that more than 1300 organizations currently manage SII assets of USD 502 billion, involving over 800 asset managers [2]. SII business, invested by the asset managers, aim to solve social and environmental problems.

Founders of SII business entities are generally known as social entrepreneurs. Some of them finance their business with social capital funds reserved for SII. Social capital funds are generally available in developed economies, which aim to support social welfare and provide private-sector solutions on social issues. Some of these funds raise money in developed economies and support projects underdeveloped countries in Africa and in South America. For example, Swiss-based Bamboo Finance (www.bamboofinance.com) currently invests in microfinance institutions in Africa; UK-based Acumen Fund (acumen.org) invests in social businesses in Africa and India subcontinents; US-based Grassroots Business Fund (www.gbfund.org) invests in Kenya, Peru, and India. There are generally less social capital funds available in Asia.

In Hong Kong, there are growing discussions and practices of SII. Some organizations occasionally conduct seminars and sharing sessions for those participating in SII. However, there is limited formal study on SII on this economy. This research aims to report three business cases of SII for marginalized communities (the disadvantaged) in Hong Kong, relating them to general discussion on SII in the global market. These three business cases deal respectively with displaced old tailors, elderly and 
wheelchair-bound people, and single-parent families. They are purely profit-driven, with no or extremely limited support from governmental organizations, public organizations or NGOs. They are "doing well and doing good" for those who should be originally supported by traditional social welfare organizations. Hong Kong government does not classify them as social enterprises because of their profit-making nature. Also, they issue shares to private investors who can share dividend payouts. These three business cases have been operated for more than 5 years. They match closely the social target areas of OECD SII attributes [3]. However, their social impacts are neither externally certified nor fully reported. In addition to document SII practices in Hong Kong, this paper draws attention to policymakers on how to support privately-owned SII entities and help them grow further.

This paper will proceed as follows. Section 2 will discuss general background and literature on SII in advanced economies. Section 3 introduces the case study method and data to be used in this research. Section 4 reports the case details. Section 5 discusses issues arising from those case results and put forward some recommendations to support SII. Section 6 concludes the paper.

\section{Background and Literature Review}

Most social entrepreneurs raise funds through their own contacts, high net-worth individuals, family offices and charity foundations [4]. One funding difficulty for SII startups is that they are less attractive to draw the attention of traditional institutional investors, such as sovereign wealth funds, banks, insurance companies, retirement or pension funds, hedge funds, foundation, investment advisors and mutual funds. Traditional institutional investors tend to focus on stable financial returns and acceptable risk levels $[4,5]$. They may exercise influence on the management of companies $[6,7]$ because tend to exercise their voting rights in a company, actively engaging in corporate governance [6,8] and increasing corporate transparency [9]. If a social project is able to convince institutional investors to invest in it, it will definitely strengthen its capital base, assist management, improve corporate governance and increase transparency. To attract capitals from these institutional investors, social entrepreneurs of an SII business entity should get prepared to adopt the standards required by institutional investors with regard to its strategy, business operations, scalability, accountability, and performance measurement.

Many SII business entities are still in their early stages of business life cycles, with unstable business, thinly-staffed operation, lack of customers, inexperienced management staff and no profit [10]. The survival rate of SII business entities is low if funding is diluted [11,12] or if their founders give up running the business [12]. In a statistic compiled by the US Department of Commerce Census Bureau (http://www.sba.gov) in 2011, 30\% of all new SII business entities fail in their first two years, and an additional 50\% fail within next five years. Given their high risk of failure, traditional institutional investors typically request high expected financial returns. That could weaken their ability to provide social goods.

\subsection{Funding for Social Goods: For-Profit vs. Non-For-Profit}

There is always unclear definition on SII. Some may easily associate SII with the following names: socially responsible investing, social investing, mission-driven investing, sustainable and responsible investing, value-based investing, ethical investing, responsible investing or social finance [13-15]. Previous studies show that, despite less clear definition on SII, academics and practitioners generally accept that SII aims to generate financial returns plus non-financial impact including social, environmental or cultural impact. The non-financial impact with positive contribution on societies is sometimes broadly regarded as social impact [16].

To attract SII-minded investors, SII has developed itself to be an asset class for professional institutions such as pension funds, endowments and banks in the form of investible funds. Many SII-related funds are established, investing in equities, bonds, loans, and other financial instruments. They cover various sectors and claim that they support business with positive impact to societies. They select projects with their targeted impact or with their said ESG criteria [16-18]. 
However, with such broad interpretation on non-financial impact and blurred standards on measuring the impact [13,16], many conventional investments can be easily included as SII.

In 2015, OECD differentiates SII from conventional investments by identifying some attributes of SII. One important attribute of SII is social target area, which includes aging, disability, health, children and families, public order and safety, (affordable) housing, unemployment, and education/training. This attribute of social target area narrows the scope of SII and makes it different from other investments for sustainable development [3]. Other OECD attributes on SII include "compulsory reporting/external certification/legally-binding constraints", "neither fully public nor fully private", and "formal evaluation (on social impact)". It seems that not all SII-related entities are able to comply with these additional three SII attributes.

In 2016, Impact Reporting and Investment Standards (IRIS) develops its criteria on classifying social impact objectives [19], which include "access to clean water and sanitation, access to education, access to energy, access to financial services, access to information, affordable housing, agricultural productivity, capacity building, community development, conflict resolution, disease-specific prevention and mitigation, employment generation, equality and empowerment, food security, generate funds for charitable giving, health improvement, human rights protection or expansion, and income/productivity growth". Obviously, the IRIS provides a broader coverage on the definition of social impact than OECD.

Some consider SII as social welfare provided to the needed in society. Traditional organizations for social welfare are mostly funded by either governments or charity funds or individual donors. The amount for such funding is far less than the amount a society generally spends on conventional investments, including direct investments and financial investments. A charity fund may donate $5 \%$ of the fund per year to selected projects and keep the remaining $95 \%$ on conventional investments generating desired returns. Traditionally, pension funds account for a majority of investible asset base among institutional investors. However, involvement of pension funds into social impact investing is still relatively small. Only $3 \%$ of pension funds are involved in impact investing [20]. Individuals tend to allocate their wealth on bank deposits, bonds, stocks, and real estate. Very few consider SII unless they want themselves to be social entrepreneurs. If SII business becomes a profitable asset class, it will surely attract both institutional and individual investors and increase the amount of funds allocated on profitable projects with social goods.

There are several issues on making SII to an investable asset. First, SII-related projects must be for-profit organizations. Investors consider mainly profit-driven businesses which will be able to pay dividends to shareholders and interests to debtholders. Second, those SII projects should have financially sustainable business models on generating stable income and then paying back investors for the long term (say, at least 3 to 5 years). Third, in addition to financial returns, SII projects are able to provide evidence on their social impacts. If there is an easy-to-use metric on social impact or an accreditation body certifying their social impacts, SII business entities will be more able to attract funds from investors with SII focus. These SII investors include individuals, family offices, foundations, development finance institutions, banks, and funds [21].

Since the late 2000s, there has been a growth in social impact investors who look for SII opportunities. In April 2017, the Ford Foundation in the USA announces its plan to invest US $\$ 1$ billion on mission-related investing over the next 10 years. The growth of SII funds is expected to continue. There are two main types of impact funds-one with a goal of achieving comparable market return, and the other that is purely non-profit in nature. Fund managers such as Root Capital [22] and Bamboo Finance are impact funds investing in socially-responsible and socially-minded companies with a goal to achieve market return. Fund manager such as Acumen Fund [23] is an impact fund that invests in projects with a social cause and accepts a below-market return on their investment. Some classify impact funds into three categories, namely commercial impact funds, non-commercial impact funds, and quasi-commercial impact funds [13]. The first two types are similar to profit-driven entities and non-profit organizations respectively. For the last type in this classification, public entities provide their 
first tranche of capital and private investors provide subsequent tranches of capital. This is similar to the OECD SII attribute on "neither fully public nor fully private" [3].

As most of the social business entities are privately owned and some of them are at their infancy company life cycle, professional fund managers may be able to extend their knowledge in traditional private equity and venture capital investment in analyzing and evaluating an SII business. Likewise, a fund manager with financial know-how can offer investors with a better portfolio to diversify their risk and enhance their return. Professional fund managers also provide a platform for the family offices and pension funds to invest into SII business through some diversified SII funds. In addition, the professional fund managers can design SII funds matching specific risk profile of investors. In sum, the professional fund managers help make social impact investing an acceptable investible asset class.

\subsection{Issues on Measuring Social Impact}

Currently, there is no universal definition and measurement standard on social impact. Measuring social impact not only helps SII-focused investors to identify suitable investment opportunities but also helps social business entities prove their work to potential SII-focused investors [3,24-27].

In June 2013, during the G8 Social Impact Investment Forum, former UK Prime Minister David Cameron announced The Social Impact Investment Taskforce which objective was to catalyze the development of the social impact investment market. The task force brings together government officials and senior figures from the world of finance, business and philanthropy across the G8 countries. One aim for the group is to develop a set of general guidelines [28] for impact measurement practice for use by social impact investors globally to ensure that impact measurement is widely recognized and employed as a fundamental part of the practice of social impact investing (https: //www.gov.uk/government/groups/social-impact-investment-taskforce).

Many of recent publications from various social impact communities such as EVPN and AVPN also highlight the need of impact measurement. The social investment community has been promoting the use of Impact Reporting and Investment Standards (IRIS) and Global Impact Investing Rating System (GIIRS). The Impact Reporting and Investment Standards (http://iris.thegiin.org) (IRIS), is a shared framework that aims to collect data, including financial, operational and product impact, by sectors [19]. Global Impact Investing Ratings System (http://giirs.org) (GIIRS), assesses the social and environmental impact of social businesses and social capital funds with a ratings and analytics approach analogous to Morningstar investment rankings and Capital IQ financial analytics. The two academic methods that are currently being used in performance measurement are the Balanced Scorecard (BSC) and Social Return of Investment (SROI). The Balanced Scorecard (BSC), developed by Kaplan and Norton in 1992 [29], is used by the social business community in performance measurement and strategic management. Social Return of Investment (SROI) maintained by SROI Network [30] is a principle-based method for measuring extra-financial value (i.e., environmental and social value not currently reflected in conventional financial accounts) relative to resources invested. In sum, there is no generally-accepted standard on measuring social impact.

\subsection{SII in Hong Kong}

SII has been rising in Hong Kong and is much motivated by the drive of entrepreneurship among the universities graduates. Young entrepreneurs have good intention to want to "do good" and in their start-up ventures incorporated with social or environmental missions. However, many of those initiatives from young people are in the form of social enterprises which aim to generate income and reinvest most surpluses for the businesses or for the society. The Home Affair Bureau of the Hong Kong government has a unit to promote social enterprises, which defines a social enterprise as follows:

"A social enterprise is a business to achieve specific social objectives such as providing the services (such as support service for the elderly) or products needed by the community, creating employment and training opportunities for the socially disadvantaged, 
protecting the environment, funding its other social services through the profits earned, etc. Its profits will be principally reinvested in the business for the social objectives that it pursues. In other words, the primary objective of a social enterprise is to achieve its social objectives, rather than maximizing profits for distribution to its shareholders."

(https://www.social-enterprises.gov.hk/)

Hong Kong government currently partners with external organizations to offer seed monies to support social enterprises. Also, the government offers business contracts to social enterprises. These contracts may include catering services, cleaning services or others in public facilities and government premises. This is a form of indirect governmental subsidy provided to social enterprises. Many of these social enterprises are units under charity and social welfare organizations and thus do not need to pay profit tax. These social enterprises are alternatives to traditional social welfare for socially-disadvantaged people. However, these social enterprises are still far from the interest of investors who mainly look for financial returns in addition to social returns. Without adequate financial returns, investors are reluctant to enter into the SII asset class.

\section{Method and Data}

This paper applies case study method to examine selected cases on social impact investing in Hong Kong. Case study research is recognised as a tool in many social science studies [31,32] with regard to education, sociology and community-based issues such as poverty, unemployment, drug addiction, illiteracy, etc. Data collection takes place mostly in 2009-2016. Our original research includes 13 business cases. All these 13 cases have evidence on their operation for at least 5 years. Therefore, many start-ups are excluded from our sample. Many of the cases are social enterprises. Some are SII business entities. One case is a government operation. Our process of data collection involves screening appropriate business cases, interviewing their business operators for several rounds, and writing the business cases. Excluding those non-profit social enterprises and government operations for the general public, this paper reports three business cases for marginalized communities, namely displaced tailors (or retired tailors), wheelchair users (including elderly) and single-parent families. Normal business operations generally do not target at these disadvantaged people. These three cases are profit-driven entities rather than social enterprises defined in Hong Kong. Meanwhile, the "social goods" of these SII cases are narrowly defined. For instance, their stakeholders are generally regarded as disadvantaged people whom should be served by traditional social welfare organizations. Although there are only three cases in this paper, they are the only SII cases in Hong Kong, which are $100 \%$ privately-owned, maintaining financially sustainable operation for more than 5 years, and focusing on marginalized communities.

\subsection{Impact Value Chain Logic Model}

Many SII businesses and social enterprises apply Impact Value Chain Logic Model [33] to help them conceptualize both breadth and depth of their impact creation. This model is advocated by Social Impact Investment Task Force in its guidelines issued in 2014 [28]. This paper follows this model to report the social impacts of the three business cases in Hong Kong. The model, shown in Table 1, is a qualitative framework for documentation instead of a quantitative measure on social impact. During the process of data collection, our researchers have open-ended dialogues with interviewees and collect facts to fill in a standard template for the model. The following table shows the standard template for data documentation which focuses on five key dimensions. 
Table 1. Impact Value Chain Logic Model (Source: W K Kellogg Foundation 2004).

\begin{tabular}{|c|c|c|c|c|}
\hline Inputs & Activities & Outputs & Outcomes & Impact \\
\hline $\begin{array}{l}\text { financial and human } \\
\text { resources to operate } \\
\text { the program }\end{array}$ & $\begin{array}{l}\text { how } \\
\text { resources are } \\
\text { used }\end{array}$ & $\begin{array}{l}\text { Units of service } \\
\text { resulting from the } \\
\text { activities }\end{array}$ & $\begin{array}{l}\text { What have change } \\
\text { for the program } \\
\text { participants }\end{array}$ & $\begin{array}{l}\text { What are the changes } \\
\text { in the organizations } \\
\text { and communities as a } \\
\text { result }\end{array}$ \\
\hline
\end{tabular}

\subsection{Impact Creation}

Some social enterprises and NGOs apply Social Return of Investment (SROI) to measure social impact [30]. Since we have no detailed financial data from the interviewees, this paper does not measure any SROI of the cases. Instead, this paper applies Maslow's theory of hierarchy of needs [34] to identify which needs the cases to satisfy their target stakeholders. Maslow suggests that people are motivated to fulfill basic needs before moving on to the needs of self-esteem and self-actualization. Many of the basic needs at the bottom are basic physical requirements including the need for food, water, sleep, and warmth. In fact, basic needs and safety and security are issues that social organizations aim to accomplish with these people. The five hierarchical needs are:

- Physiological needs: air, food, drink, shelter, warmth, sex, sleep

- Safety needs: protection from elements, security, order, law, stability, freedom from fear

- Love and belongingness needs: friendship, intimacy, affection and love (from work group, family, friends, romantic relationships)

- Esteem needs: achievement, mastery, independence, status, dominance, prestige, self-respect, respect from others

- Self-Actualization needs: realizing personal potential, self-fulfillment, seeking personal growth and peak experience

The paper will comment on impact creation of the three cases along the Maslow's pyramid.

\section{Case Results}

This section documents the facts ion collected from the three cases and summarizes their impact with Impact Value Chain Logic Model in a box format.

\subsection{Case 1: Bonham Strand Tailors (Bonhamstrand.hk)}

Background: Bonham Strand Tailors is a bespoke tailor commercial entity formed in 2012. It is a social business aims to preserve the traditional art of western suit tailoring in Hong Kong and to provide a decent earning and dignity to the old displaced tailors. Its stakeholders are shareholders (original shareholder and SOW Asia (SOW Asia is an SII fund founded by ex-investment banker in Hong Kong 2009. (http://www.sowasia.org))), the management, old tailors, trainee tailors, and customers. The social entrepreneur, Brian Ng, an American Chinese, felt called after meeting with the business operators of L plus $\mathrm{H}$ knitwear, a social business, to minister to a group of old tailors to preserve Hong Kong craftsmanship in man suit tailoring and to provide a safe and fair employment environment for these tailors. Hong Kong was once flourished with tailors with professional craftsmanship and efficiency in the 50s and 60s. Even Lee Kuan Yew, the former Prime Minister of Singapore, was inspired by the friendliness and efficiency of Hong Kong small business owners. He was deeply impressed with the Hong Kong tailors where he decided to have a suit tailored during his first visit to Hong Kong in the late 1950s. He said [35] "I had a suit tailored within 12 hours, measured in the morning, a fitting in the afternoon and the suit delivered to my cabin on the ship that night. It made a deep impression on me. Singapore tailors do not work at that speed."

Social Mission and Execution: Bonham Strand Tailor's social missions are (a) preservation of the Hong Kong craftsmanship in suit tailoring, and (b) providing a safe environment and employment to 
old Hong Kong tailors. As Hong Kong advances with economic growth, most tailors are displaced with increasing cost of doing business in Hong Kong. Younger generation usually lacks interest for such craft. Many tailors in their 70s find it hard to run their own shops. Bonham Strand aims to provide a safe, comfortable and fair environment for these tailors to work together. It pools together experienced tailors under one roof and provides a common pool of resources of machinery, equipment and shared profit.

Financial Sustainability: The business operates on a commercial concern charging customers a commercial rate that is comparable to the market rate for tailor suit. The business makes the customers aware of the company's social mission. Those customers get well-tailored suits made by experienced tailors and feel meaningful on doing social good. SOW Asia invested in Bonham Strand Tailor in 2013 and exited the investment in 2016. The valuation SOW Asia paid for Bonham Strand Tailor in 2013 and received in the sale is not disclosed.

Performance Measurement: Bonham Strand Tailors does not publish how they measure social impact creation. It does not have an official method to measure social impact creation. Evaluating social impact is simply observing from the workers about their enthusiasm in their work. Interviews with the tailors show that the tailors are happy to be working at Bonham Strand Tailors. They comment positively on the open and clean environment, fair and reasonable compensation, and are appreciative of contributing with their skills. They enjoy working at Bonham Strand Tailors, sharing that those fellow tailors are like a family where they work as a team and help one another out. It is unlike the situation when they were young. Many of them were cautious and suspicious from their past bad experience when Brian originally invited them to join Bonham Strand Tailors. Overtime, Brian have gained their trust. Although there is no official method in measuring social impact creation, the passion of the old tailors exhibits self-actualization, self-worth and appreciation [34] that Bonham Strand Tailors bring to the tailors. The company started its Lai Chi Kok workshop with four tailors only. It later grew to 12 tailors in the next six months. Bonham Strand Tailor now has a retail shop in Lai Kwan Fong Central, and two workshops in Kowloon, being able to house as many as 35 tailors and apprentices.

Observation: Research on Bonham Strand Tailor is based on observation, interviews, conversation, and public media. The impact value chain of Bonham Strand Tailors is shown in Table 2. Brian was passionate with this idea of helping the displaced old tailors in Hong Kong inspired by another social enterprise in the garment industry that social mission is to preserve Hong Kong craftsmanship and to produce quality 'made in Hong Kong" knit products. Brian eventually starts Bonham Strand Tailors with the funding of venture capitalists. Brian has put lots of effort to make Bonham Strand Tailors a success. The business actively engages the media and public social network to promote the social mission of the company. This helps the public learn more about the social nature of Bonham Strand. That, in turn, generates industry interest to partner with Bonham Strand. Cirque du Soleil, a Canadian musical company, donated workbench, equipment, and fabric to Bonham Strand in 2012. Italian fabric, Cerruti dal 1881, partners with Bonham Strand with quality fabric at social enterprise cost. Brian consistently spreads the message that the company is a social enterprise since the inception although it is not a charitable organization (In Hong Kong, charitable organizations must be non-profit organizations and focus on several approved areas of services. Such a Hong Kong law is based on a similar law in UK [36]). He always takes the opportunity to speak of the social mission the company is aiming to carry out from meeting with potential investors, partners, services providers and etc. The company gains media attention with press coverage resulting in business and donation of equipment. Nevertheless, Brian is truly industrial in ensuring the service quality is tip-top. At the beginning when the company's workshop was located in Lai Chi Kok industrial estate, Brian personally travelled to Central to take measurement from customers and even personally deliver finished suits over. Unlike other social entrepreneurs who are recent young graduate with a passionate heart, Brian is at his thirties and showing more mature character. He is a graduate from University of Chicago and New York University with many years of experiences in finance and corporate restructuring. Although he does not have the experience in tailoring, he compensates it with prudent financial planning and business strategy. 
Table 2. Impact Value Chain of Bonham Strand Tailors (Targeted stakeholder: displaced old tailors as employees).

\begin{tabular}{|c|c|c|c|c|}
\hline Inputs & Activities & Outputs & Outcomes & Impact \\
\hline $\begin{array}{l}\text { Setup tailor company } \\
\text { with business } \\
\text { management, } \\
\text { workshop, } \\
\text { equipment customer } \\
\text { sourcing, } \\
\text { and marketing with } \\
\text { funding }\end{array}$ & $\begin{array}{l}\text { Create employment } \\
\text { for old tailors and to } \\
\text { preserve the } \\
\text { craftsmanship of } \\
\text { western suit tailoring }\end{array}$ & $\begin{array}{l}\text { They started with } 4 \\
\text { tailors but grown to } \\
12 \text { tailors within six } \\
\text { months. } \\
\text { Old tailors who were } \\
\text { displaced by their } \\
\text { aged and by the } \\
\text { popularity of } \\
\text { off-the-shelf western } \\
\text { suits. }\end{array}$ & $\begin{array}{l}\text { Bonham Strand offered job } \\
\text { and a stable income to } \\
\text { displaced old tailors, } \\
\text { and preserve the skill of } \\
\text { tailoring craftsmanship. } \\
\text { Between the retail shop in } \\
\text { Lan Kwai Fong and the } \\
\text { two workshops in } \\
\text { Kowloon, they should be } \\
\text { able to house as many as } \\
35 \text { tailors and apprentices. }\end{array}$ & $\begin{array}{ll}\text { - } & \text { Decent wages } \\
\text { - } & \text { Dignity } \\
\text { - } & \text { Safe environment } \\
\text { - } & \text { Belongingness } \\
\text { - } & \text { Mastery } \\
\text { - } & \text { Self-respect } \\
\text { - } & \text { Self-actualization }\end{array}$ \\
\hline
\end{tabular}

Conclusions: Bonham Strand Tailors is registered as a for-profit company. However, it has a clear social mission. It carries out its social mission where both the old tailors as employees and its investors as shareholders are both taken care of. It is a success case when its social mission is accomplished and the business is financially viable. The business is profitable and the tailors earn a salary, bonus and profit share. This motivates the tailors to work for themselves and align their interest with that of its equity investors. It has clear social goals and the social outcome in impact creation is clearly observable per the Kellogg Logic Model. As a business, its challenges lie in keeping the tailors engaged, and ensuring their willingness to pass down their skill to the next generation with on-the-job training. The company is financially sustainable. Social impact creation on Maslow's hierarchy of needs is also multi-dimensional. The company is a Socially Responsible Business rather than a Revenue Generating Social Enterprise. It competes in with other tailors in Hong Kong, charging similar market rate. It has clear social objectives in its work. It has the ability to distribute profits as it is currently upstreaming profit to the social impact fund and shareholders. It does not have much overhead or fixed cost except for rental, workshop and salary. This company is ideal for impact investors who seek financial returns and social returns from their investment. The company's challenge is securing supply of displaced old tailors and growing the business. Many traditional tailors are used to work independently in their own studios or from their home. Impact investors of this company should expect below market returns and be good with high social impact.

\subsection{Case 2: Diamond Cab}

Background: A social business that provides legal, safe and comfortable transportation for wheelchair-bound people. The social entrepreneur, Doris Leung, started this concept in 2007 when she was exploring wheelchair accessible transportation for her mother. The stakeholders are wheelchair-bound people (elderly and disabled), drivers, taxi license lessor, management and shareholders. She shares that there were wheelchair-accessible vans available but they operated with no proper license, poor hygiene and no proper insurance protection. These vans are very active in transporting the elderly between nursing homes, clinics and hospitals on a regular basis. These vans charge fares 2 to 3 times higher than a typical taxi. Compassionate for her mother, she was driven to seek a safer and more comfortable way of transportation for the aged and the disabled. She had worked with Social Venture Hong Kong (SVHK) for over three years building up a network of trusted partners including the taxi companies and elderly homes. Diamond Cab started its operation in 2011, operating seven wheelchair-accessible cabs with a capacity to make 100 single trips per day. Its sponsors [37] expresses that Diamond Cab gives disabled passengers new opportunities to enjoy "the satisfaction of a happy social life and a convenient lifestyle, just like any one of us." It currently has over three thousand active users on its database, over 50 business partners, and over 250 media exposure. Diamond Cab is a commercial entity, charging commercial rates to its customers from the services it provides. It is one of the companies supported by Social Venture Hong Kong. It continues to 
seek private and corporate sponsorship on physical taxi purchase, corporate advertisement and etc. Diamond Cab participated in a global "Meet the Venture Contenders" competition for social creation with a prize of USD 1 million organized by Chivas Regal.

Social Mission and Execution: Diamond Cab seeks to fill a gap that is missing in the market. Its business is to provide safe and reliable transportation for wheelchair-bound people. Its social mission is to create awareness for wheelchair-bound people including disabled and elderly, to give them a better quality of life with ease of transportation. Social Venture Hong Kong was the early sponsor in 2007 helping Doris brainstorm, perfect her business plan, raise funds, and connect her to the taxi companies. One of her concern is the existing vans transporting wheelchair-bound people are illegal operators in Hong Kong and do not have proper passenger insurance. The partnership with taxi companies allows her to operate wheelchair-bound cabs in a legal, safe and professional way. Social Venture Hong Kong is instrumental in finding taxi companies and in convincing them to be participants in this social venture. However, the taxi companies need to purchase new vehicles that can fit a wheelchair comfortably. Those taxi drivers will have to incur a higher fuel cost for those wheelchair-bound cabs. Taxi drivers need to be re-trained to operate those wheelchair-bound vehicles. These cabs charge the same flag down fare as a normal taxi. This taxi service is very well received in the society, always fully booked in advance for fetching elderly between home and hospital for check-ups, and treatments, to and from restaurants and malls, and other neighbours too. The recipients are happier with the improved mobility, and hence enjoy a better quality of life. The family of the recipients are more at peace knowing that their loved ones are ferried by responsible, licensed and reliable taxi company and drivers.

Financial Sustainability: Diamond Cab is registered as a for-profit company. However, it does accept donation as it continues to accept taxi donation to increase its fleet. It also accepts corporate sponsorship to reduce its overhead and operating expenses. Diamond Cab is a private company and its financials are not made available for the intense of this research. However, it is an asset-light company as all the fleet are not donated assets by sponsors. Its revenue model is to collect rental from the taxi drivers, and its expense is the taxi license rental from taxi companies. Its other expenses include marketing, administration and call centre fees. Advertisement income on the face of the cab is also a revenue stream but small. Diamond Cab is innovative in engaging investors. Investors can earn rental income from the company in the taxi vehicles they sponsor. Hence, the investors are happy getting rewarded with monthly cash flow and the satisfaction of "doing well and doing good" socially.

Performance Measurement: Diamond Cab is probably the only social business actively publishing social impact information. It publishes basic information on the number counts of people benefited from its services. It reports that it has completed $80,000+$ wheelchair-bound trips and have provided employment to 17 drivers in its latest annual report. However, it falls short of measuring the results of these services. Passengers' satisfaction and their improvement on quality of life are highly subjective and impossible to quantify. The rating by the same passenger may differ per trip and be affected by other factors as well. Per Maslow's hierarchy of needs (Maslow, 1970) safety needs was satisfied. Wheelchair-bound passengers gain dignity in a proper means of transportation and have quality of life improved with independence. These satisfy the self-respect in Maslow's esteem needs.

Observation: The impact value chain of Diamond Cab is shown in Table 3. Our data collection is conducted with public meetings with the founder, founder speaking events and public media coverage, company impact reports, its websites and observation of the company since 2010. Doris is an active promotor of Diamond Cab. She appears on seminar, conference, TEDx to promote social entrepreneurship and most importantly Diamond Cab. Diamond Cab has benefited from this. The problem with Diamond Cab is managing growth. It has a problem of not enough cabs to handle the demand for such a service. Hence, there are a number of other competitors leveraging Doris' success and implementing the same business model. They are cannibalizing Diamond Cab market share. However, such competition brings better services and competitive pricing to the community it serves, which is beneficial to the community of wheelchair-bound people and social impact can be multiple. 
Conclusions: Diamond Cab is incorporated as a for-profit company. It has a simple business model that it does a good job filling in the social gap of being very focused on wheelchair-bound people. The reception by the public of the use of Diamond Cab is overwhelming which invites other service providers to compete in this market. The fare per trip is not cheap and is not necessarily affordable by working class people. Nevertheless, it is probably the right pricing strategy for now with only 6 cabs in operations. As Diamond Cab is dependent on donors to pay for the purchase of cab, it has a scaling problem. If other competitors are able to grow their fleet faster and offering a more reasonable fare, Diamond Cab may lose its market share and competitive advantages. The company is financially sustainable. Social impact creation on Maslow's hierarchy of needs is one-dimensional and straight forward. The company is a Socially Responsible Business rather than a Revenue Generating Social Enterprise. It charges above market rate and competes with other commercial services, yet has clear social objectives in its work. It has the ability to distribute profits. Its business is profitable, and media report helps promote the company's social mission to the public. It does not have much overhead or fixed cost because the taxi cars are donated to the company. Its main expenses are in payment to the drivers and the taxi licensing fees. The company's challenge is there is no barrier of entry. Its surplus is dependent on others to donate the taxi to them. Currently, impact investors are the taxi donors who collect taxi rentals from their "donation". Impact investors of the company should expect a below market financial return but satisfy with social impact.

Table 3. Impact Value Chain of Diamond Cab (Targeted stakeholder: wheelchair-bound disable people as customers).

\begin{tabular}{|c|c|c|c|c|}
\hline Inputs & Activities & Outputs & Outcomes & Impact \\
\hline $\begin{array}{l}\text { Setup company } \\
\text { with business } \\
\text { management, } \\
\text { partnership with } \\
\text { taxi company, taxi } \\
\text { cab, and drivers }\end{array}$ & $\begin{array}{l}\text { Make available } \\
\text { licensed safe and } \\
\text { reliable } \\
\text { transportation for } \\
\text { wheelchair-bound } \\
\text { people }\end{array}$ & $\begin{array}{l}7 \text { cabs and } 17 \text { drivers } \\
\text { made } 97,185 \text { trips } \\
\text { since } 2011 \text { (per its } \\
2016 \text { impact report) }\end{array}$ & $\begin{array}{l}\text { There is a lot of demands } \\
\text { for wheelchair-bound } \\
\text { people and their families } \\
\text { who want a proper and } \\
\text { safe transportation. } \\
\text { More cabs will allow the } \\
\text { company to provide fill } \\
\text { these demands }\end{array}$ & $\begin{array}{ll}\text { - } & \text { Safety } \\
\text { - } & \text { Dignity } \\
\text { - } & \text { Better quality of life } \\
& \text { with ease } \\
& \text { of transportation }\end{array}$ \\
\hline
\end{tabular}

\subsection{Case 3: Light Be Social Realty}

Background: Light Be Social Realty is a social business founded by Ricky Yu in 2013. Light Be serves as a real estate management company working with landlords who are socially-minded to provide a safe and comfort living quarters to single family tenants.

Social Mission and Execution: Ricky was motivated to help with the condition of sub-divided housing (NB: It is a very small room with poor conditions) and increasing social problems caused by sub-divided homes in Hong Kong. Light Be runs an asset-light business model. It leases an apartment from individual and corporate landlords and subleases it to a group of single family tenants who would otherwise be living in subdivided homes. The social purpose is to give the single-family tenants, especially the women and children, a safe environment to live together. At the same time, it allocates resources to help the single parent enhance their skills so that they can improve their financial conditions over a period of three years. Typically, in a 3-bedroom apartment, there will be three different single-family tenants living together. The families share the common living room and kitchen for everything from socializing, watching TVs, playing games and sharing a meal together. Light Be runs a selection process to pair the families with similar backgrounds so that they can create an ecosystem to support each other. Light Be also engages skill enhancement to help those single parents learn and acquire new skill so as to improve their opportunity of upward mobility within the society. The apartment will be free up after three years and be leased to another set of single family tenants so that it can continue to benefit others in needs. The landlords are socially-minded that they commit to lease their apartments to Light Be at a below-market rental for those single family tenants. Rather than donating the property as a charity, the landlords are just leasing the properties out enjoying 
a rental income. In 2016, Light Be reached a major milestone converting a dormitory into its first Light Housing project [38]. It is situated in Sham Tseng that can house around 90 single-parent families.

Financial Sustainability: Light Be operates an asset-light model. It acts as a property manager matching a landlord and tenants. The company, however, provides many value-added services, such as screening single-parent families, pairing them and enhancing their employment skills. Landlords are the investors who engage Light Be's services. They receive rental return at below-market rate but benefit single-parent families. Light Be offers an excellent platform that allow individual landlords to resolve a social problem. Light Be proves that it does not need to be a large and well-capitalized government organizations to help relief the sub-divided housing problem in Hong Kong. Light House project, which is a government premise, should be a game changer since it is able to accommodate 90 families. The rent from the Hong Kong Government is just a token $\$ 1$ (Naomi NG, 2016) - a significant support for social housing project. However, Light Be needs to get funds to support renovation for making the premise suitable for living. Eventually, the company was able to raise HK\$22 million from Chow Tai Fook Charity Foundation (Naomi NG, 2016) for expense of renovation.

Performance Measurement: Light Be confirms it does not perform any measurement on the work it does. It does not publish impact report or an annual report for public use. Further conversation with the company's founder and his staff confirm they have no such request from their sponsors. Though Light Be does not report any impact creation, its work is clearly exhibited in the people they help. There is a waiting list of single-parent families applying for rental at Light Be. The company obviously brings better living environments for single-parent families than what sub-divided housing offers. It generates a healthy environment for parents and their children, offering the parents skill enhancement for jobs.

Observation: The impact value chain of Light Be Social Realty is shown in Table 4. Our research is conducted with interviews with the founder and some landlords, email, media reports and news articles on Light Be, as well as on Light Be's sponsors and partners. Social Venture Hong Kong is an earlier investor helping Ricky with the resources of business idea and connecting him with potential impact investors who own properties. Light Be's noble idea of running a property management business to offer co-sharing option to single-parent families is unique and creative. It appeals to the landlords who are socially minded and gives one-stop hassle-free solution to the landlords. It runs all administration services of tenant mix selection, tenant dynamics management, rental collection services on behalf of the landlords. It also goes the extra mile of assisting the tenants to form a caring community to live together, assisting the tenants for skill upgrade and retraining, and assisting in the transition out when they gain more financial resources. Its model is unique and there is no other competitor, except those offering low-quality sub-divided housing. Social media and press interviews help improve Light Be's profile that help the company reach out to more socially minded landlords.

Conclusions: Though Light Be is set up as a commercial entity with a clear social mission and a simple business model. It has an asset-light business model and its revenue model is based on the management fee which is percentage of rental proceed. The revenue is offset against all administration cost and consultation cost. It incurs more cost as compared to other property management company as it has to hire more people to deal with screening, pairing, monitoring and physical visits, as well as job placement for those tenants. There is a no shortage of growth as evidenced from the long waitlist of applications. The major risk against Light Be is the default risk or against any non-payment of rent from some tenants. The company is financially sustainable. Social impact creation on Maslow's hierarchy of needs is multi-dimensional. The company delivers its social goals of affordable housing for single-parent families. It satisfies basic physiological needs and safety needs in Maslow's hierarchy. In addition, the company aims to develop friendship among the families, which belongs to belongingness needs. With skill enhancement, the tenants gain financial independent, social mobility, and independent. These are esteem needs. Furthermore, the families gain hope through the process and realize their potential to do better in life. It fulfils self-actualization need. 
Table 4. Impact Value Chain of Light Be (Targeted stakeholder: single-parent families as tenants).

\begin{tabular}{|c|c|c|c|c|}
\hline Inputs & Activities & Outputs & Outcomes & Impact \\
\hline $\begin{array}{l}\text { Setup company with } \\
\text { business } \\
\text { management, } \\
\text { marketing, financial } \\
\text { management and } \\
\text { funding; and secure } \\
\text { rental properties } \\
\text { from individual } \\
\text { landlords }\end{array}$ & $\begin{array}{l}\text { Screen } \\
\text { single-parent } \\
\text { family application } \\
\text { and make a } 3 \text { year } \\
\text { leasing agreement } \\
\text { with selected } \\
\text { single-parent } \\
\text { families. }\end{array}$ & $\begin{array}{l}130 \text { number of } \\
\text { single-family } \\
\text { households } \\
\text { benefited from the } \\
\text { program. } \\
40 \text { number of } \\
\text { individual } \\
\text { landlords "do well } \\
\text { by do good". } \\
\text { Safe community }\end{array}$ & $\begin{array}{l}\text { Rental tailored to } \\
\text { each family ability to } \\
\text { afford and is } \\
\text { typically HK\$3-5000 } \\
\text { per month. } \\
\text { Tenants receive } \\
\text { training and skill } \\
\text { upgrade to allow } \\
\text { career and social } \\
\text { mobility. } \\
\text { Community } \\
\text { Quality of life }\end{array}$ & $\begin{array}{ll}\text { - } & \text { Integrate new } \\
\text { - } & \text { Security } \\
\text { - } & \text { Dignity } \\
- & \text { Education } \\
- & \text { Belongingness } \\
- & \text { Self-confidence } \\
- & \text { Self-respect } \\
- & \text { Self-improvement } \\
- & \text { Hope }\end{array}$ \\
\hline
\end{tabular}

\section{Discussion and Recommendations}

The above three cases in Hong Kong aim to benefit marginalized communities. Their target stakeholders include displaced old tailors, elderly and wheelchair-bound people, and single-parent families. Information on the cases is collected from structured interviews. These business entities are not charitable organizations but they are able to contribute both financial and social returns. As their financial figures are not disclosed, this paper is unable to evaluate exactly their degree of profitability. What is known is their financially sustainable operation for more than 5 years. It is believed that their profitability is partly attributed to external donations and subsidy by founders and employees. Since they are ordinary business entities, these SII business entities do not get any tax subsidy like what other charitable organizations get. Also, these SII business entities get no subsidy from existing government schemes for social welfare organizations and social enterprises in Hong Kong. These three cases match closely the social target area of SII attributes advocated by OECD. The first case deals with unemployment. The second case deals with disability. The third case deals with affordable housing. However, all these three cases have no external certification on their social impact. Some even have no or limited report on their social impacts. Also, they are $100 \%$ privately-owned, different from the model of public-private partnership in the OECD SII attributes. Obviously, the three cases are inconsistent with all OCED SII attributes. It echoes again the issue of less clear definition on SII and challenges whether public-private partnership must be an attribute on SII.

SII is a good business concept promoting care to the society. It also helps resolve many issues associated with marginalized communities and disadvantaged people. In the coming decades, any societies will face their aging problems. How to support elderly people, especially disabled ones, and to engage senior workers will be an important theme of SII.

If the private sector is able to provide good solutions to those social issues, governments should support them. Currently, many governments, like the government in Hong Kong, establish funding schemes to support non-profit social welfare organizations and non-profit social enterprises. All these subsidy schemes are inapplicable to the three cases. The governments may need to think about new initiatives to support privately-owned and profit-driven entities with recognized social missions and grow them with capitals from private investors. To attract more private funds to support SII, this paper recommends the following initiatives for policymakers.

\subsection{SII Business License for Tax Deduction}

To encourage SII business, there should be tax incentives for business operators, investors (equity or debts) and donors. The three chosen cases indicate that they are not qualified for any tax exemption because they are simply treated as normal businesses. According to Hong Kong laws, debtholders are required to pay interest tax unless interest fees are paid by licensed banks or by specially-approved bonds. If an individual donates monies or tangible assets to an SII organization, he/she cannot get any tax deduction from their income. It is because an SII business entity is not recognized as a charitable 
organization. Apparently, the current tax system does not favour SII business. The government may need to establish a new business license which allows SII businesses to have tax exemption.

\subsection{Subsidy on Premises}

Currently non-profit organizations can easily get subsidies from governments on the use of premises for their operations. These premises may be idle government offices or abandoned schools. SII business entities, as normal business entities, are not qualified for this kind of subsidies. Currently, many governments set up incubation centres to support technology start-ups. Can this incubation concept be extended to SII start-ups? If those SII start-ups turn out to be financially sustainable, they can move out from the incubation centres.

\subsection{Accreditation of SII Businesses}

Many countries are developing standards on ESG (environmental, Social and Government) reporting and accreditation. It is less difficult for environmental certification as there are a number of global and national standards to follow. However, there is no clear definition of how to measure social impact. Currently, both OECD and GIIN have their classification criteria on social impact objectives $[3,19]$. These classification criteria provide a baseline to recognize SII business. How to measure social impact remains to be an area deserving further study [27,39]. Measuring social impact is associated with licensing SII business for tax benefits or other government supports. In addition, without unclear measurement standards on social impacts, investors are required to spend more efforts of due diligence to find out suitable business entities generating social impacts. This increases their search cost in SII. As a result, they may go back to conventional investments or narrowly focus on a small number of well-established SII business entities.

Suppose that we have a local accreditation body for SII businesses, which may be a government-supported and/or an industry-based entity. It conducts on-site examination on SII businesses, provides standard templates for reporting social impacts and finally certifies those SII business operators. This will provide enormous convenience to potential investors for finding out target investments with SII focus, to the government for subsidizing SII business, and to SII business entities for soliciting funds from investors and donors. It is generally agreed that there is no universal standard on defining and measuring social impact. Such accreditation body may broadly incorporate most commonly-applied standards as its certification standards. As long as it has its SII measurement standards established, it will enable local SII entities to get certified and get funded.

\subsection{Social Impact Funds}

Currently, many governments set up innovation or venture capital funds to support technology start-ups. Is it possible for the government establish social impact funds to invest in those financially sustainable SII business entities? These funds can have monies jointly from public and private enterprises. Financially sustainable SII business entities may get their funds, via equities, debts or convertible debts, to expand their business. Some non-profit social enterprises with financially sustainable business models may transform themselves to be profit-driven operations and get funds from the social impact funds. If a social impact fund grows to a certain size, it may get listed on the stock exchange to attract a wide community of investors. Currently, many utility-related assets and venture capitals are listed on the stock exchanges. Sizable social impact funds with profit records can also be listed. A listed social impact fund may help their investees to report their social impacts in a better way so that the fund can attract global investors.

It is obvious that the three SII cases in Hong Kong are "doing well and doing good" for the society and should deserve to have better supports from the society and Hong Kong government. As suggested by OECD in 2019 [18], governments should identify what role they want to play, those needs of both services providers and beneficiaries, their policy objectives relating to SII, and their appropriate 
interventions or supports on the process of SII. With better governmental supports, SII-related business and investment funds will be able to thrive quickly.

\section{Conclusions}

Doing business with social mission has become a trend among social entrepreneurs who are founders of SII business. Some investment funds, managed by professional fund managers, are designated to invest in SII business. Investors with SII focus tend to look at both financial returns and social returns. These investors, including founders of SII business, generally do not mind to have less financial returns from an investment if the investment demonstrates good social returns. However, this paper has discussed two major issues on SII: Less clear definition of SII and less clear measurement standards on social impacts. Most previous studies on SII focus on the practices in North America and Europe. In Hong Kong, SII business is still at its early stage of development. Thus, there is very limited research about SII practices in Hong Kong. This paper is pioneer research on SII in Hong Kong, focusing on three SII cases for marginalized communities in Hong Kong. Although there is growing interest in SII in Hong Kong, it is observed that there is no generally-accepted definition and impact measurement regarding SII in Hong Kong. The three chosen cases are 100\% privately-owned, being profit-driven and issuing shares to private investors. They are classified as neither social enterprises nor charitable organizations. It is because Hong Kong law requires a social enterprise or a charitable organization to be totally non-for-profit. Thus, the three cases are not qualified for any subsidy from the Hong Kong government. The three cases are financially sustainable with operation for over 5 years. They serve the unemployed, the disable and families looking for affording housing respectively. They comply with the social target area of OECD SII attributes but fail to meet with other OCED SII attributes.

It seems that policymakers may need to consider how to support privately-owned SII business and help them get more funding from private investors. The paper recommends the following initiatives to policymakers to strengthen SII development, namely tax reduction for business entities and donors, incubation centres for SII start-ups, social impact funds engaging both public and private capitals, and a local accreditation body to certify social impact.

Although there are only three cases in this sample of studies, they fully represent those privately-owned and financially sustainable SII business entities for marginalized communities in Hong Kong. Surely there are charitable organizations and social enterprises currently running their business for the marginalized communities. They are not the target sample of this study. As SII tend to evolve fast, this paper mainly provides insights for future SII development in Hong Kong

Defining SII and measuring social impact remain two critical issues of future research of SII. It is believed that an SII business entity certified by a recognized third-party on its social impacts will find it easy to get supports by governments and SII-focused investors. Both OECD SII attributes and IRIS Social Impact Objectives have provided good starting points for SII definition and social impact measurement. A local accreditation body may simply tune these SII attributes to fit them into local SII practices. As SII contributes to social welfare, local and foreign direct investment, and creation of job opportunities, governments should take their active role in facilitating SII business operation and their fundraising from the private sector.

Author Contributions: R.C.Y.Y.: Conceptualization, methodology, analysis and draft; M.C.S.W.: writing and editing. Funding: This research received no external funding and the APC was funded by City University of Hong Kong. Acknowledgments: We are thankful to the social impact investing companies in Hong Kong for their information sharing.

Conflicts of Interest: The authors declare no conflict of interest.

\section{References}

1. US SIF Foundation. Report on Socially Responsible Investing Trends in the United States 2012; US SIF Foundation: Wahsington, DC, USA, 2012. 
2. Mudaliar, A.; Dithrich, H. Global Impact Investing Network. Sizing the Impact Investing Market; Global Impact Investing Network: New York, NY, USA, 2019.

3. OECD. Social Impact Investment: Building the Evidence Base; OECD: Paris, France, 2015.

4. VanOsnabrugge, M.; Robinson, R.J. Angel investing: Matching Startup Funds with Startup Companies: The Guide for Entrepreneurs, Individual Investors, and Venture Capitalists; Jossey-Bass: San Francisco, CA, USA, 2000.

5. Sherman, A.J. Raising Capital: Get The Money You Need to Grow Your Business; AMACOM of Division American Management Association: New York, NY, USA, 2012.

6. Gillan, S.L.; Starks, L.T. Corporate Governance Proposals and Shareholder Activism: The Role of Institutional Investors. J. Financ. Econ. 2000, 57, 275-305. [CrossRef]

7. Smith, M.P. Shareholder Activism by Institutional Investors: Evidence from CalPERS. J. Financ. 1996, 51, $227-252$. [CrossRef]

8. Bhojraj, S.; Sengupta, P. Effect of Corporate Governance on Bond Ratings and Yields: The Role of Institutional Investors and Outside Directors. J. Bus. 2003, 76, 455-476. [CrossRef]

9. Bushee, B.J.; Noe, C.F.; NOE. Corporate Disclosure Practices, Institutional Investors, and Stock Return Volatility. J. Account. Res. J. Account. Res. 2000, 38, 171-202. [CrossRef]

10. Nour, D. The Entrepreneur's Guide to Raising Capital; Praeger: Westport, CT, USA, 2009.

11. Cressy, R. Small Business Failure: Failure to Fund or Failure to Learn? In Entrepreneurship, Small and Medium-Sized Enterprises, and The Macroeconomy; Cambridge University Press: Cambridge, MA, USA, 1999; $405 p$.

12. Watson, J.; Everett, J. Defining Small Business Failure. Int. Small-Bus. J. 1993, 11, 35-48. [CrossRef]

13. Chiappini, H. Social Impact Funds: Definition, Assessment and Performance; Palgrave Macmillan: London, UK, 2017.

14. Lehner, O.M. Routledge Handbook of Social and Sustainable Finance; Routledge: London, UK, 2016.

15. Nicholls, A.; Paton, R.; Emerson, J. Social Finance; Oxford Scholarship Online: Oxford, UK, 2015.

16. Höchstädter, A.K.; Scheck, B. What's in a Name: An Analysis of Impact Investing Understandings by Academics and Practitioners. J. Bus. Ethics 2015, 132, 449-475. [CrossRef]

17. La Torre, M.; Calderini, M. Social Impact Investing Beyond the SIB: Evidence from the Market; Palgrave Macmillan: London, UK, 2018.

18. OECD. Social Impact Investment 2019: The Impact Imperative for Sustainable Development; OECD: Paris, France, 2019.

19. IRIS. Social Impact Objectives (OD6247) Impact Reporting and Investment Standards; IRIS: New York, NY, USA, 2016.

20. GIIN. Annual Impact Investor Survey 2017; Global Impact Investing Network: New York, NY, USA, 2017.

21. ImpactBase. Depth and Diversity of Opportunities in the Impact Investing Fund Landscape; ImpactBase: New York, NY, USA, 2016.

22. Root Capital. Performance Report Q1 2017; Root Capitral: Cambridge, MA, USA, 2017.

23. Koh, H.; Karamchandani, A.; Katz, R. From Blueprint to Scale: The Case for Philanhropy in Impact Investing; The Bill and Melinda Gates Foundation: Seattle, WA, USA, 2012.

24. Clark, C.; Rosenzweig, W.; Long, D.; Olsen, S. Double Bottom Line Project Report: Assessing Social Impact in Double Bottom Line Ventures; Working Paper Series; Center for Responsible Business, University of California Berkeley: Berkeley, CA, USA, 2004.

25. Maas, K.; Liket, K. Social Impact Measurement: Classification of Methods. In Environmental Management Accounting and Supply Chain Management; Burritt, R., Schaltegger, S., Bennett, M., Pohjola, T., Csutora, M., Eds.; Springer: Berlin, Germany, 2011; pp. 171-202.

26. Nicholls, J. Why Measuring and Communicating Social Value Can Help Social Enterprise Become More Competitive? Cabinet Office, Office of the Third Sector: London, UK, 2007.

27. Rawhouser, H.; Cummings, M.; Newber, S.L. Social Impact Measurement: Current Approaches and Future Directions for Social Entrepreneurship Research. Entrep. Theory Pract. 2019, 43, 82-115. [CrossRef]

28. Social Impact Investing Taskforce. Measuring Impact. Impact Measurement Working Group; Social Impact Investing Taskforce: London, UK, 2014; Available online: https://www.thinknpc.org/resource-hub/impact-m easurement-working-group-measuring-impact (accessed on 17 May 2019).

29. Kaplan, R.S.; Norton, D.P. The Balanced Scorecard-Measures that Drive Performance. Harv. Bus. Rev. $1992,1,79$.

30. Millar, R.; Hall, K. Social Return on Investment (SROI) and Performance Measurement. Public Manag. Rev. 2013, 15, 923-941. [CrossRef]

31. Dacin, M.T.; Dacin, P.A.; Tracey, P. Social Entrepreneurship: A Critique and Future Directions. Org. Sci. 2011, 22, 1203-1213. [CrossRef] 
32. Galaskiewicz, J.; Barringer, S.N. Social Enterprises and Social Categories. In Social Enterprises; Palgrave Macmillan: London, UK, 2012; pp. 47-70.

33. W.K. Kellogg Foundation. W.K. Kellogg Foundation Logic Model Development Guide: Using Logic Models to Bring Together Planning, Evaluation, and Action; WK Kellogg Foundation: Battle Creek, MI, USA, 2004.

34. Maslow, A.H. Motivation and Personality, 3rd ed.; Longman: London, UK, 1970.

35. Yew, L.K. A Tale of Two Cities - Twenty Years On. Li Ka Shing Lecture by Mr Lee Kuan Yew, Senior Minister of Singapore at the University of Hong Kong. National Archive of Singapore. 2014. Available online: http://www.nas.gov.sg/archivesonline/data/pdfdoc/lky19921214.pdf (accessed on 17 May 2019).

36. UK Court Case. Income Tax Special Commissioners v Pemsel: HL 20 Jul 1891. Available online: https://swarb.co.uk/ income-tax-special-commissioners-v-pemsel-hl-20-jul-1891 (accessed on 17 May 2019).

37. Cab, D. Diamond Cab Impact Report 2013-2016: What Did We Change for Hong Kong with Our Wheelchair Accessible Taxi? Available online: https:/www.diamondcab.com.hk/files/impact-report-2016.pdf (accessed on 17 May 2019).

38. Ng, N. Hong Kong Government Teams up with Social Enterprise to Provide Cheap Housing for as Many as 90 Families. South China Morning Post. Available online: https:/www.scmp.com/news/hong-kong/educatio n-community/article/2025349/hong-kong-government-teams-social-enterprise (accessed on 17 May 2019).

39. Reisman, J.; Olazabal, V.; Hoffman, S. Putting the "Impact" in Impact Investing: The Rising Demand for Data and Evidence of Social Outcomes. Am. J. Eval. 2018, 39, 389-395. [CrossRef]

(C) 2019 by the authors. Licensee MDPI, Basel, Switzerland. This article is an open access article distributed under the terms and conditions of the Creative Commons Attribution (CC BY) license (http://creativecommons.org/licenses/by/4.0/). 